\title{
Concentration- and flux-based ozone dose-response relationships for five poplar clones grown in North China
}

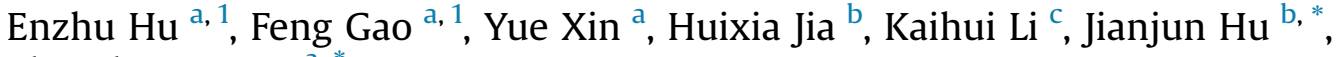 \\ Zhaozhong Feng a, \\ a State Key Laboratory of Urban and Regional Ecology, Research Center for Eco-Environmental Sciences, Chinese Academy of Sciences, Shuangqing Road 18, \\ Haidian District, Beijing, 100085, China \\ b State Key Laboratory of Tree Genetics and Breeding, Key Laboratory of Tree Breeding and Cultivation of State Forestry Administration, Research Institute of \\ Forestry, Chinese Academy of Forestry, Dongxiaofu 1, Haidian District, Beijing, 100091, China \\ ${ }^{c}$ State Key Laboratory of Desert and Oasis Ecology, Xinjiang Institute of Ecology and Geography, Chinese Academy of Sciences, Urumqi, 830011, China
}

\section{A R T I C L E I N F O}

\section{Article history:}

Received 25 June 2015

Received in revised form 14 August 2015

Accepted 20 August 2015

Available online 1 September 2015

\section{Keywords:}

Stomatal conductance

Ozone flux

Dose-response relationship

Critical level

Poplar

\begin{abstract}
A B S T R A C T
Concentration- and flux-based $\mathrm{O}_{3}$ dose-response relationships were developed for poplars in China. Stomatal conductance $\left(g_{s}\right)$ of five poplar clones was measured to parameterize a Jarvis-type multiplicative $g_{s}$ model. The maximum $g_{s}$ and other model parameters varied between clones. The strongest relationship between stomatal $\mathrm{O}_{3}$ flux and total biomass was obtained when phytotoxic ozone dose $(P O D)$ was integrated using an uptake rate threshold of $7 \mathrm{nmol} \mathrm{m}^{-2} \mathrm{~s}^{-1}$. The $\mathrm{R}^{2}$ value was similar between flux-based and concentration-based dose-response relationships. Ozone concentrations above 28 $-36 \mathrm{nmol} \mathrm{mol}{ }^{-1}$ contributed to reducing the biomass production of poplar. Critical levels of $A_{0 T}$ (accumulated $\mathrm{O}_{3}$ exposure over $40 \mathrm{nmol} \mathrm{mol}^{-1}$ ) and $P O D_{7}$ in relation to $5 \%$ reduction in total biomass for poplar were $12 \mu \mathrm{mol} \mathrm{mol}^{-1} \mathrm{~h}$ and $3.8 \mathrm{mmol} \mathrm{m}^{-2}$, respectively.
\end{abstract}

๑) 2015 Elsevier Ltd. All rights reserved.

\section{Introduction}

Tropospheric ozone $\left(\mathrm{O}_{3}\right)$ is an important phytotoxic air pollutant and a significant greenhouse gas formed by photochemical reactions among nitrogen oxides, volatile hydrocarbons and carbon monoxide in the atmosphere (Dumont et al., 2014; Feng et al., 2015). The background $\mathrm{O}_{3}$ level over the mid latitudes of the Northern Hemisphere has increased continuously between $0.5 \%$ and $2 \%$ per year over the last 30 years (Vingarzan, 2004). It is predicted to rise up to $80 \mathrm{nmol} \mathrm{mol}{ }^{-1}$ in 2100 , accompanied by episodes of $\mathrm{O}_{3}$ peaks occasionally exceeding $200 \mathrm{nmol} \mathrm{mol}^{-1}$ (IPCC, 2013; Richet et al., 2012).

Forest ecosystems, which cover $31 \%$ of the Earth's land area and constitute the most important carbon sinks, could be highly vulnerable to $\mathrm{O}_{3}$ damage (FAO, 2010; Fowler et al., 2009; Sitch et al., 2007). Ozone affects tree health through stomatal uptake, causing visible foliar injury, accelerated leaf senescence, reduced

\footnotetext{
* Corresponding authors.

E-mail addresses: hujj@caf.ac.cn (J. Hu), fzz@rcees.ac.cn (Z. Feng).

1 Both authors contributed equally to this work.
}

photosynthesis, and impaired stomatal function (Feng et al., 2014; Zhang et al., 2011, 2014b). The increasing ozone concentration contributes to a decline in forestry productivity linked to economic losses (Felzer et al., 2007; Percy and Karnosky, 2007; Pye, 1988). A variety of detrimental changes at the biochemical, physiological and molecular levels have been demonstrated in conifers and deciduous trees (Koch et al., 1998; Kopper and Lindroth, 2003; Richet et al., 2011, 2012; Zhang et al., 2014a). Experimental evidence indicates that not only species but also cultivars, genotypes and clones, show different sensitivity to $\mathrm{O}_{3}$ (Calatayud et al., 2011; Castagna et al., 2015; Dumont et al., 2014; Häikiö, 2009; Paoletti and Grulke, 2010; Zhang et al., 2012, 2014c).

In the past, the impact of $\mathrm{O}_{3}$ on vegetation was quantified using the dose-response relationship based only on atmospheric $\mathrm{O}_{3}$ concentrations, such as $A O T_{40}$ (accumulated hourly $\mathrm{O}_{3}$ concentration over a threshold of $40 \mathrm{nmol} \mathrm{mol}{ }^{-1}$ during daylight hours) (Fuhrer et al., 1997). Nowadays, it has been gradually replaced by the $P O D_{Y}$ (phytotoxic ozone dose over a threshold of $Y$ ) index defining the amount of $\mathrm{O}_{3}$ entering the leaves through the stomata (Gerosa et al., 2015; LRTAP Convention, 2010; Mills et al., 2011). This latter index, which has been described using different names in the 
literature, such as CUO (cumulative uptake of $\mathrm{O}_{3}$ ), or $A F s t Y$ (accumulated stomatal flux above a threshold of $Y$ ) (Azuchi et al., 2014; Uddling et al., 2004), takes into account the $\mathrm{O}_{3}$ flux by modeling $\mathrm{O}_{3}$ stomatal conductance $\left(g_{\text {sto }}\right)$ using multiplicative algorithms, such as Jarvis (1976).

It is generally accepted that the damage of $\mathrm{O}_{3}$ to plants is mainly caused by the amount of $\mathrm{O}_{3}$ entering into the leaf interior through the open stomata (Kerstiens and Lendzian, 1989). Stomatal conductance of plants is one of the crucial mechanisms of $\mathrm{O}_{3}$ sensitivity (Dumont et al., 2013; Guidi et al., 2001). Stomatal $\mathrm{O}_{3}$ uptake considers both biological traits and climatic factors. Therefore, it is better for assessing the adverse effects of $\mathrm{O}_{3}$ on the plants than external $\mathrm{O}_{3}$ concentrations (Emberson et al., 2000b; Uddling et al., 2004).

Among different tree species, poplars have received particular attention because of the fast growth rate and relatively high stomatal conductance (Woo and Hinckley, 2005). There are 53 species of poplar distributed in 22 provinces of China (not including crossbreed and imported species), covering a total area of over 10 million ha with a total standing stock of 426 million $\mathrm{m}^{3}$ (Liang et al., 2006; Xu et al., 2009). Different species or clones of poplar have shown different sensitivity to $\mathrm{O}_{3}$ with respect to visible leaf injury (Hoshika et al., 2012; Novak et al., 2005; Ryan et al., 2009; Strohm et al., 1998), damaged photosystems (Bernacchi et al., 2003; Guidi et al., 2001; Ranieri et al., 2001), and reduced growth (Isebrands et al., 2001; Matyssek et al., 1993; Mooi, 1980). However, the knowledge of $\mathrm{O}_{3}$ dose-response relationships for poplar, which could be an effective tool for $\mathrm{O}_{3}$ risk assessment, is still limited. It was hypothesized that the difference in $\mathrm{O}_{3}$ sensitivity could lead to different parameter values of stomatal conductance model for different poplar species or clones.

The overall objectives of the present study were: (1) to parameterize the stomatal conductance model of poplar clones widely used in China; (2) to develop exposure concentration and fluxbased $\mathrm{O}_{3}$ dose-response relationships; and (3) to define the critical levels for protecting poplar against $\mathrm{O}_{3}$ damage.

\section{Materials and methods}

\subsection{Experimental site and plant materials}

The experiment was conducted in Changping $\left(40^{\circ} 19^{\prime} \mathrm{N}\right.$, $116^{\circ} 13^{\prime} \mathrm{E}$ ), northwest of Beijing in a warm temperate and semihumid continental climate. The annual mean temperature in Changping is $11.8{ }^{\circ} \mathrm{C}$ and the total annual precipitation is $550 \mathrm{~mm}$.

Rooted cuttings of five hybrid poplar clones were cultivated at the Chinese Academy of Forestry Sciences. The following clones were used: ' $84 \mathrm{~K}$ ' (Populus alba $\times$ P. glandulosa), '107' $(P . \times$ euramericana cv. '74/76'), '90' (P. deltoides $\times$ P. cathayana $\mathrm{cv}$. Senhai 2), '546' ( $P$. deltoides cv. '55/56' $\times$ P. deltoides cv. 'Imperial'), and '156' $(P$. deltoides $\times P$. cathayana). The cuttings were transplanted into 20 L circular plastic pots on April 20, 2014 when they were about 65 days old. Pots were filled with local light loamy farmland soil. Seedlings with similar height and stem basal diameter (Table S1 and S2) were selected for this study and pre-adapted to open-top chamber conditions for 10 days before $\mathrm{O}_{3}$ fumigation. All plants were manually irrigated up to soil field capacity with tap water at 1-2 days interval to avoid drought stress.

When most leaves turned yellow and the growth of height and basal stem diameter had stopped, the plants were harvested and separated into leaves, stems, and roots. All plants were harvested between Sep. 13 and 28, 2014 (see details in Table S3). The plant organs were oven-dried at $80^{\circ} \mathrm{C}$ until a constant mass was reached.

\subsection{Ozone treatments}

The experiment was conducted in six open-top chambers (OTC, octagonal base, $12.5 \mathrm{~m}^{2}$ of growth space and $3.0 \mathrm{~m}$ of height, covered with toughened glass) with different treatments: charcoal filtered ambient air (CF), non-filtered ambient air (NF), and NF with targeted $\mathrm{O}_{3}$ addition of $20(\mathrm{NF}+20), 40(\mathrm{NF}+40), 60(\mathrm{NF}+60)$, and $80(\mathrm{NF}+80) \mathrm{nmol} \mathrm{mol}^{-1}$ for 8 -h average $\mathrm{O}_{3}$ concentration. Ozone was generated from pure oxygen by an $\mathrm{O}_{3}$ generator (HY003, Chuangcheng Co., Jinan, China) and then mixed with ambient air using a fan (1.1 kW, $1080 \mathrm{~Pa}, 19 \mathrm{~m}^{3} \mathrm{~min}^{-1}$, CZR, Fengda, China) to achieve the target $\mathrm{O}_{3}$ concentration at the top of the canopy in the fumigation treatments. There was no chamber replication for each treatment. In order to eliminate the positional and chamber effects (Potvin and Tardif, 1988), the plant positions within each OTC were changed every 3-5 days, and all seedlings were switched between chambers once a month, according to Feng et al. (2011). Each chamber functioned as one of six treatments randomly at each month during the growing season. The concentration in each chamber was changed every month according to the corresponding treatment.

Six to eight potted plants per poplar clone were exposed to each treatment except there was no '156' in the NF+20 chamber. The daily maximum fumigation period was $9 \mathrm{~h}$ (from 08:30 to 17:30) when there was no rain, fog, mist, or dew, according to the protocols in Free Air Ozone Concentration Enrichment System (Feng et al., 2010; Morgan et al., 2006).

\subsection{Ozone and climate monitoring}

The concentrations of $\mathrm{O}_{3}$ in the OTCs were continuously monitored using an UV absorption $\mathrm{O}_{3}$ analyzer (Model 49i, Thermo Scientific, USA), via a Teflon solenoid valve switch system, which collected air from sampling points at approximately $10 \mathrm{~cm}$ above the plant canopy. The monitors were calibrated by a 49i-PS calibrator (Thermo Scientific, USA) before the experiment and once a month during the experiment. Fumigation targets and average $\mathrm{O}_{3}$ concentrations ( $24 \mathrm{~h}, 12 \mathrm{~h}$, and $8 \mathrm{~h}$ ) for all treatments are presented in Table 1.

Air temperature $(T)$, relative air humidity $(R H)$, and photosynthetic photon flux density (PPFD) under the ambient condition and inside the OTCs were measured every 5 min using a weather station (Campbell Scientific, North Logan, Utah, USA). Water vapor pressure deficit (VPD) was estimated using Eq. (1):

$V P D=\left(1-\frac{R H}{100}\right) \times 0.611 \times \exp \left(\frac{17.502 \times T}{T+240.97}\right)$.

Hourly means of environmental variables were employed in $\mathrm{O}_{3}$ flux calculations. The range of $T, V P D$, and $P P F D$ was $6.94-46.48{ }^{\circ} \mathrm{C}$, $0.00-9.15 \mathrm{kPa}$, and $0-1358 \mu \mathrm{mol} \mathrm{m}^{-2} \mathrm{~s}^{-1}$, respectively, from May 7 to Sep. 29, 2014. Compared with ambient air, the average air temperature and relative humidity in the OTCs were increased by $1.52{ }^{\circ} \mathrm{C}$ and $1.65 \%$, respectively.

Table 1

$\mathrm{O}_{3}$ concentrations ( $\mathrm{nmol} \mathrm{mol}{ }^{-1}$, mean $\pm \mathrm{SE}$ ) during the experiments from May 7 to Sep. 29, 2014.

\begin{tabular}{lllc}
\hline Target & 24-h average & $\begin{array}{l}\text { 12-h average, } \\
\text { 08:00-20:00 }\end{array}$ & $\begin{array}{c}\text { 8-h average, } \\
\text { 09:00-17:00 }\end{array}$ \\
\hline $\mathrm{CF}$ & $25.7 \pm 0.9$ & $28.1 \pm 1.1$ & $28.0 \pm 1.3$ \\
$\mathrm{NF}$ & $35.7 \pm 1.2$ & $48.4 \pm 1.6$ & $53.2 \pm 1.8$ \\
$\mathrm{NF}+20$ & $41.4 \pm 1.3$ & $59.4 \pm 1.7$ & $67.1 \pm 1.9$ \\
$\mathrm{NF}+40$ & $46.3 \pm 1.4$ & $69.4 \pm 2.0$ & $79.5 \pm 2.3$ \\
$\mathrm{NF}+60$ & $52.8 \pm 1.6$ & $81.9 \pm 2.5$ & $95.4 \pm 2.9$ \\
$\mathrm{NF}+80$ & $58.1 \pm 1.8$ & $92.4 \pm 2.8$ & $108.7 \pm 3.3$ \\
\hline
\end{tabular}




\subsection{Stomatal conductance measurements and modeling}

The stomatal conductance of five poplar clones from NF and $\mathrm{NF}+40$ treatments were measured in situ with a Li-6400 photosynthesis system (LiCor, Lincoln, Nebraska, USA) during the experiment in 2014. A red/blue LED light source chamber was used to avoid shading part on the leaf. The PPFD was adjusted every 30 min to get close to the sun light PPFD. The temperature and humidity was not controlled during the measurements. The $g_{\text {sto }}$ value was stabilized for at least $1.5 \mathrm{~min}$ before it was recorded. The diurnal variation in $g_{\text {sto }}$ was measured every $1-2$ h, i.e. every measurement cycle, from 9:00 AM to 6:00 PM on fully developed leaves in the middle layer of leaves of $4-8$ replicated trees of each treatment. After discarding the obvious outliers (i.e. some data that were outside the mean \pm 2 SD of all measurements at each measurement cycle for each clone, around $10 \%$ of the total measurements), all valid $g_{\text {sto }}$ and their linked meteorological data were averaged for each clone at each treatment in one measurement cycle, and were used to calibrate the stomatal conductance model. The Jarvis-type multiplicative stomatal conductance model was applied (Emberson et al., 2000a; Jarvis, 1976; LRTAP Convention, 2010). It includes mathematical functions for phenology $\left(f_{\text {phen }}\right)$, photosynthetically photon flux density $\left(f_{\mathrm{PPFD}}\right)$, water vapor pressure deficit $\left(f_{\mathrm{VPD}}\right)$, temperature $\left(f_{\text {temp }}\right)$, soil water potential $\left(f_{\mathrm{SWP}}\right)$ and $\mathrm{O}_{3}\left(f_{\mathrm{O}}\right)$.

$$
\begin{aligned}
g_{\text {sto }}= & g_{\max } \times \min \left(f_{\text {phen }}, f_{\mathrm{O}_{3}}\right) \times f_{\mathrm{PPFD}} \times \max \left[f_{\text {min }},\left(f_{\text {temp }} \times f_{\mathrm{VPD}}\right.\right. \\
& \left.\left.\times f_{\mathrm{SWP}}\right)\right],
\end{aligned}
$$

where $g_{\text {sto }}$ denotes the actual stomatal conductance of $\mathrm{O}_{3}\left(\mathrm{mmol} \mathrm{O}_{3}\right.$ $\mathrm{m}^{-2}$ projected leaf area (PLA) $\mathrm{s}^{-1}$ ), which is converted from the stomatal conductance of water vapor using a conversion factor of 0.663 to account for the difference in the molecular diffusivity of water vapor to that of $\mathrm{O}_{3} ; g_{\max }$ refers to the highest value of stomatal conductance of $\mathrm{O}_{3}\left(\mathrm{mmol} \mathrm{O}_{3} \mathrm{~m}^{-2} \mathrm{PLA} \mathrm{s}^{-1}\right)$; and $f_{\min }$ is the relative minimum stomatal conductance (fraction of $g_{\max }$ ).

$f_{\text {phen }}$ is calculated based on a fixed time interval:

when $A_{\text {start }} \leq y_{\mathrm{d}}<\left(A_{\text {start }}+f_{\text {phen_c }}\right)$,

$$
f_{\text {phen }}=\left(1-f_{\text {phen_a }}\right) \times\left[\left(y_{\mathrm{d}}-A_{\text {start }}\right) / f_{\text {phen_c }}\right]+f_{\text {phen_a }},
$$

when $\left(A_{\text {start }}+f_{\text {phen_c }}\right) \leq y_{\mathrm{d}}<\left(A_{\text {end }}-f_{\text {phen_d }}\right)$,

$f_{\text {phen }}=1$

when $\left(A_{\text {end }}-f_{\text {phen_d }}\right) \leq y_{\mathrm{d}}<A_{\text {end }}$,

$$
f_{\text {phen }}=\left(1-f_{\text {phen_b }}\right) \times\left[\left(A_{\text {end }}-y_{\mathrm{d}}\right) / f_{\text {phen_d }}\right]+f_{\text {phen_b }} \text {, }
$$

where $y_{\mathrm{d}}$ represents the year day; $A_{\mathrm{start}}$ and $A_{\text {end }}$ are the year days for the start and end of $\mathrm{O}_{3}$ fumigation period, which was May 7,
2014 and the corresponding harvest date in Table S3, respectively; $f_{\text {phen_a }}$ and $f_{\text {phen_b }}$ denote the maximum fraction of $g_{\max }$ that $g_{\text {sto }}$ takes at the start and the end of the fumigation period for $\mathrm{O}_{3}$ flux, respectively. $f_{\text {phen_c }}$ and $f_{\text {phen_d }}$ are model parameters to describe the shape of the function within the fumigation period.

The response of $g_{\text {sto }}$ to leaf temperature $\left(f_{\text {temp }}\right)$ was expressed as Eq. (6).

when $T_{\min }<T<T_{\max }$,

$$
f_{\mathrm{temp}}=\left(\frac{T-T_{\min }}{T_{\mathrm{opt}}-T_{\min }}\right) \times\left(\frac{T_{\mathrm{max}}-T}{T_{\max }-T_{\mathrm{opt}}}\right)^{b_{t}}, \quad b_{t}=\frac{T_{\mathrm{max}}-T_{\mathrm{opt}}}{T_{\mathrm{opt}}-T_{\min }}
$$

when $T<T_{\min }$ or $T>T_{\max }$,

$f_{\text {temp }}=f_{\text {min }}$,

where $T$ denotes the leaf temperature $\left({ }^{\circ} \mathrm{C}\right), T_{\min }$ and $T_{\max }$ are the minimum and maximum leaf temperatures at which stomatal closure occurs to $f_{\min }, T_{\text {opt }}$ corresponds to the optimum leaf temperature.

Response functions for radiation and VPD were described as follows:

$f_{\mathrm{PPFD}}=1-\exp \left(-\right.$ light $\left._{\mathrm{a}} \times P P F D\right)$,

where light $\mathrm{t}_{\mathrm{a}}$ is model parameter; the unit of PPFD is $\mu \mathrm{mol} \mathrm{m} \mathrm{m}^{-2} \mathrm{~s}^{-1}$;

$f_{\mathrm{VPD}}=\min \left\{1, \max \left\{f_{\min }, \frac{\left(1-f_{\min }\right) \times\left(V P D_{\min }-V P D\right)}{V P D_{\min }-V P D_{\max }}+f_{\min }\right\}\right\}$,

where the unit of VPD is $\mathrm{kPa}$. It was assumed that there is no strong correlation between $f_{\mathrm{VPD}}$ and $f_{\text {temp }}$, even though VPD was estimated based on temperature (Pleijel et al., 2002).

These mathematical functions were parameterized using a boundary line technique, which was first introduced by Webb (1972), and has been widely used in plant and soil science models (Bhat and Sujatha, 2013; Blanco-Macías et al., 2010; Lewandowski and Schmidt, 2006; Topp et al., 2013; Vizcayno-Soto and Côté, 2004). It was based on the principle that biological materials have an upper response limit to a given variable (Imhoff et al., 2010). The construction and fitting of boundary lines took the following four steps (Schmidt et al., 2000).

(1) Scattergrams were plotted between relative stomatal conductance (fraction of $g_{\max }$ ) as dependent variable and each of the independent variables, such as $y_{\mathrm{d}}, T, P P F D$, and $V P D$, for each poplar clone.

(2) The $x$-axis of each scattergram was divided into 8 sections of the same length. The data set of the scattergram, therefore, was split into 8 equidistant segments to cover all the points.

(3) For each segment, 99\% percentile was computed and used as the boundary point. It was assumed to be affiliated to the arithmetic mean of the $x$-values of the corresponding section.

(4) On each entire scattered data set, the boundary points were plotted against the arithmetic centers of the segments from which they were derived. The curves were then fitted to Eqs. (3)-(9), respectively. 
In previous studies, the maximum stomatal conductance $\left(g_{\max }\right)$ was measured under optimal conditions where there is no limiting effect of $V P D, P P F D$, and $\mathrm{O}_{3}$. However, such optimal conditions are difficult to achieve during measurements. In the present study, clone-specific $g_{\max }$ was estimated by fitting observed $g_{\text {sto }}$ into the bell-shaped Eq. (10) using a boundary analysis technique.

$g_{\text {sto }}=g_{\max } \times f_{\text {temp }}$

For forest trees, the response of $g_{\text {sto }}$ to $\mathrm{O}_{3}\left(f_{\mathrm{O}}\right)$ was set to 1 in Eq. (2) according to LRTAP Convention (2010). Moreover, measurements of soil water potential were unavailable and the water availability was hypothesized to be sufficient since all plants were kept well watered with manual irrigation every 1-2 days. The limitation of soil water potential on $g_{\text {sto }}$ was not considered in the calculations $\left(f_{\mathrm{SWP}}=1\right)$. The ability of this model to predict $g_{\text {sto }}$ was validated by comparing the observations and simulations.

\subsection{Stomatal ozone flux}

Stomatal flux of $\mathrm{O}_{3}$ at the leaf level $\left(F_{\mathrm{st}}\right.$, expressed on a one-sided leaf area basis) is determined by the $\mathrm{O}_{3}$ concentration at plant height and the resistance analogue principle derived from Ohm's law (Campbell and Norman, 1998), considering the leaf-boundary layer as a resistance to $\mathrm{O}_{3}$ flux connected in series with the parallel resistances of stomatal and non-stomatal leaf surfaces (Uddling et al., 2010).

$F_{\mathrm{st}}=\frac{\left[\mathrm{O}_{3}\right]_{\mathrm{can}}-\left[\mathrm{O}_{3}\right]_{\mathrm{int}}}{r_{\mathrm{b}}+r_{\mathrm{s}}+r_{\mathrm{b}} \cdot r_{\mathrm{s}} / r_{\mathrm{ns}}}$

where $\left[\mathrm{O}_{3}\right]_{\text {can }}$ and $\left[\mathrm{O}_{3}\right]_{\text {int }}$ are the $\mathrm{O}_{3}$ concentrations at the canopy top and in the intercellular air space of the leaves, respectively; $r_{\mathrm{b}}=1 / g_{\mathrm{b}}, r_{\mathrm{s}}=1 / g_{\mathrm{sto}}$, and $r_{\mathrm{ns}}=1 / g_{\mathrm{ns}}$ are the resistances for $\mathrm{O}_{3}$ flux through the leaf-boundary layer, stomatal and non-stomatal surface deposition, respectively; $g_{b}, g_{\text {sto }}$ and $g_{\text {ns }}$ represent the leaf boundary layer conductance, stomatal conductance, and nonstomatal conductance, respectively.

The non-stomatal $\mathrm{O}_{3}$ deposition to the exterior leaf surface is negligible because the cuticle is considered to be highly impermeable to $\mathrm{O}_{3}$ compared to open stomata (Kerstiens and Lendzian, 1989). Therefore, Eq. (11) can be written as:

$F_{\mathrm{st}}=\frac{\left[\mathrm{O}_{3}\right]_{\mathrm{can}}-\left[\mathrm{O}_{3}\right]_{\text {int }}}{r_{\mathrm{b}}+r_{\mathrm{s}}}$.

It is empirically assumed that the $\mathrm{O}_{3}$ concentration inside the intracellular spaces of the leaf was approximately zero (Laisk et al., 1989). Hence, Eq. (12) can be simplified as:

$F_{\mathrm{st}}=\frac{\left[\mathrm{O}_{3}\right]_{\mathrm{can}}}{r_{\mathrm{b}}+r_{\mathrm{s}}}$

The boundary layer resistance $\left(r_{\mathrm{b}}\right)$ depends on wind speed and the shape of the leaf. It can be measured with a heat transfer method (Jones, 1983) or calculated using the Unsworth et al. (1984) equation:

$r_{\mathrm{b}}=k \sqrt{d / u}$

where $k$ is the empirical coefficient, $d$ refers to the leaf mean width, and $u$ denotes the wind mean velocity at the top canopy level. In this study, the value for $r_{\mathrm{b}}$ was considered negligible because of the high velocity of the airflow through the chambers (Ryan et al., 2009).

A flux-based index $\left(P O D_{Y}\right.$, phytotoxic $\mathrm{O}_{3}$ dose above a flux threshold of $Y \mathrm{nmol} \mathrm{O}_{3} \mathrm{~m}^{-2} \mathrm{PLA} \mathrm{s}^{-1}$ ), was calculated by integrating positive values of $\left(F_{\mathrm{st}}-Y\right)$ during the fumigation period (start from May 7, 2014 to the harvest date displayed in Table S3).

$P O D_{\mathrm{Y}}=\int \max \left(F_{\mathrm{st}}-Y, 0\right) \mathrm{d} t$.

For the calculation of $P O D_{\mathrm{Y}}$, the leaf temperature was replaced by air temperature in Eq. (6) since air temperature is easily obtained from the meteorology station and this simplification does not have a large influence on the calculated PODY (Pleijel et al., 2002).

\subsection{Relationships between $\mathrm{O}_{3}$ exposure and biomass loss}

The dose-response relationship for the relative loss of total biomass was analyzed, based on the principles introduced by Fuhrer (1994). Firstly, a linear regression for each poplar clone was made between the actual biomass and accumulated $\mathrm{O}_{3}$ exposure or stomatal uptake to obtain the $y$-intercept as hypothetically maximum biomass at zero $\mathrm{O}_{3}$ exposure or uptake. The relative biomass $(R B)$ was obtained as the biomass at each $\mathrm{O}_{3}$ treatment divided by the $y$-intercept of each clone regression. The $R B$ of each $\mathrm{O}_{3}$ treatment and clone thus becomes comparable on a common, relative scale. The $R B s$ for all five poplar clones and treatments were then regressed against the $\mathrm{O}_{3}$ dose metrics.

Biomass was plotted against $\mathrm{O}_{3}$ exposure expressed as AOT with an $\mathrm{O}_{3}$ concentration threshold $(X)$ from 0 to $120 \mathrm{nmol} \mathrm{mol}^{-1}$, and as $P O D$ with the stomatal $\mathrm{O}_{3}$ flux threshold $(Y)$ ranging from 0 to $20 \mathrm{nmol} \mathrm{O}_{3} \mathrm{~m}^{-2} \mathrm{PLA} \mathrm{s}^{-1}$. AOT $\mathrm{X}$ is the accumulated $\mathrm{O}_{3}$ exposure over a concentration of $X \mathrm{nmol} \mathrm{mol}{ }^{-1}$ based on hourly averages during daylight hours. Both $A O T_{\mathrm{X}}$ and $P O D_{\mathrm{Y}}$ were calculated over the specific period for each clone in each treatment (start from May 7, 2014 to the harvest date displayed in Table S3). The test of a wide range of thresholds $X$ and $Y$ was made in order to find the relationship with the highest $R^{2}$ for the relationship between $R B$ and $\mathrm{O}_{3}$ exposure. Moreover, the $A O T_{40}$-and $P O D_{1}$-based dose-response relationships were analyzed, since they have been widely used and have been accepted by the United Nations Economic Commission for Europe (UNECE) Convention on Long-range Transboundary Air Pollution (LRTAP) in assessing the $\mathrm{O}_{3}$ effects on forests (LRTAP Convention, 2010). The $\mathrm{O}_{3}$ sensitivity of poplar could be evaluated by comparing the slope of $A O T_{40}$-or $P O D_{1}$-based dose-response relationship for poplar with the one for other forest tree species, like beech/birch and spruce, included in LRTAP Convention (2010).

\subsection{Mathematical analysis}

All calculations of stomatal conductance and fluxes, as well as the statistical analysis were performed in MATLAB, version R2013a (The MathWorks, Inc., Natick, MA, USA). The effects of $\mathrm{O}_{3}$, clone, and their interactions on total biomass were tested using ANOVA. The differences among five clones and six $\mathrm{O}_{3}$ treatments were analyzed using a multiple comparison test.

\section{Results}

\subsection{Effects of $\mathrm{O}_{3}$ treatments on the total biomass of poplar clones}

Elevated $\mathrm{O}_{3}$ had significant effects $(p<0.001)$ on the biomass production of all clones (Fig. 1). Generally, the total biomass decreased with increasing $\mathrm{O}_{3}$ concentration. Significant $\mathrm{O}_{3} \times$ clone interactions $(p<0.001)$ were also observed. The corresponding results of multiple comparison are shown in Table S4 with different letters representing significant differences $(p<0.05)$. Compared with the $\mathrm{CF}$ treatment, the $\mathrm{NF}+80$ treatment reduced total biomass 


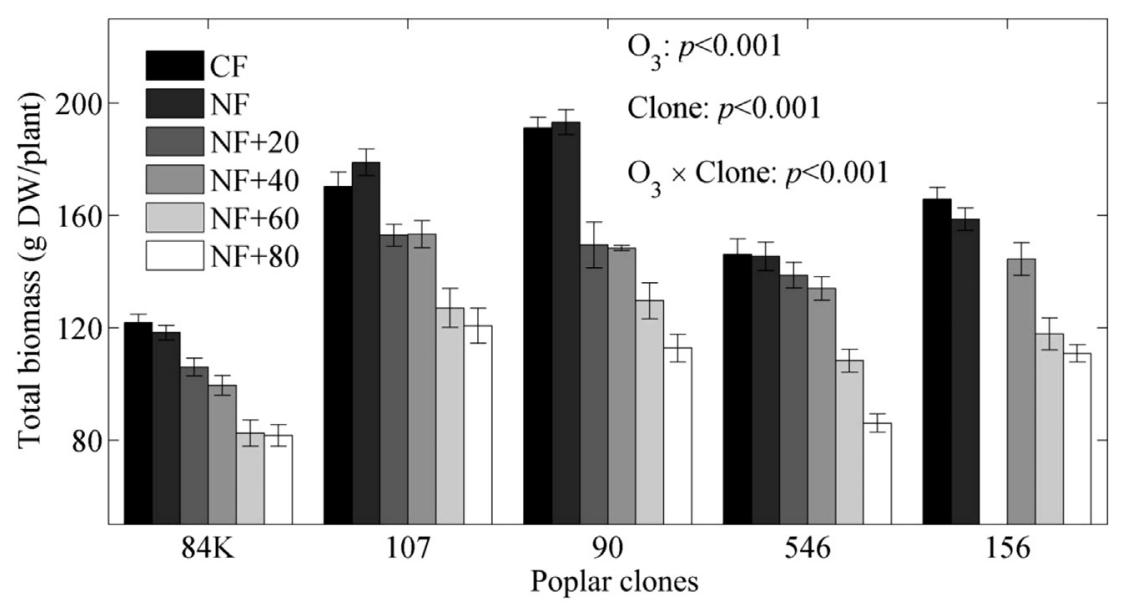

Fig. 1. Average total biomass productions ( $g$ dry weight per plant, mean $\pm \mathrm{SE}$ ) of five poplar clones in different $\mathrm{O}_{3}$ treatments.

by $29 \%$ for ' 107 ', $33 \%$ for ' $84 \mathrm{~K}$ ' and ' 156 ', and $41 \%$ for ' 90 ' and ' 546 ', respectively. However, there was no significant difference between the biomass production in the NF treatment compared to that in CF treatment across all poplar clones.

\subsection{Stomatal conductance model test}

The clone-specific parameters of the $g_{\text {sto }}$ functions are provided in Table 2. The slope of the linear regression analyses for the relationship between simulated $g_{\text {sto }}$ and observed $g_{\text {sto }}$ was 0.94 , and the coefficient of determination $\left(\mathrm{R}^{2}\right)$ was $0.72(p<0.001$; Fig. 2$)$. The regression line was not significantly different from the $1: 1$ line. The small intercept (20.4, 95\% confidence interval, 9.5 to 31.4$)$ on the $y$ axis and the slope of 0.942 (95\% confidence interval, 0.879 to 1.006 ) showed that the parameterized model performed very well.

\subsection{Ozone uptake and biomass response}

Fig. 3 displayes the different determination coefficients, slopes and intercepts of the regression of $R B$ for $A O T_{\mathrm{X}}$ and $P O D_{\mathrm{Y}}$ indices across five poplar clones with different thresholds. The $\mathrm{R}^{2}$ value in the regression of $R B$ and $A O T_{\mathrm{X}}$ increased with $\mathrm{O}_{3}$ concentration threshold up to $60 \mathrm{nmol} \mathrm{mol}^{-1}$ and then decreased (Fig. 3A). An $\mathrm{O}_{3}$ flux threshold of $7 \mathrm{nmol} \mathrm{O}_{3} \mathrm{~m}^{-2}$ PLA s $\mathrm{s}^{-1}$ provided the strongest correlation between $R B$ and $P O D_{\mathrm{Y}}$, using a step of $1 \mathrm{nmol} \mathrm{O}_{3} \mathrm{~m}^{-2}$ PLA $s^{-1}$ (Fig. 3B). For each clone, the $R^{2}$ value showed a similar pattern, but the maximum values of $\mathrm{R}^{2}$ occurred at different $\mathrm{O}_{3}$ concentration or flux thresholds (Fig. S1). The $y$-intercept of the regression of $R B$ for $A O T_{\mathrm{X}}$ indices increased with the rising of $\mathrm{O}_{3}$ concentration threshold. However, the $P O D_{\mathrm{Y}}$-based $y$-intercept values showed a peak value at an $\mathrm{O}_{3}$ flux threshold of $2 \mathrm{nmol} \mathrm{O}_{3}$ $\mathrm{m}^{-2}$ PLA s $\mathrm{s}^{-1}$. The intercepts of all regressions deviated very little from $100 \%$, which is desirable since zero exposure should be associated with no effect on biomass production. The $A O T_{\mathrm{X}}$-based intercepts were relatively higher than the $P O D_{\mathrm{Y}}$-based ones. Generally, slopes decreased with the increase of threshold value, and the greater the threshold value is, the faster the slope decreased (Fig. $3 \mathrm{~A}$ and $\mathrm{B}$ ). The response function based on $A O T_{40}$ is presented in Fig. 4A with a $\mathrm{R}^{2}$ value of 0.88 . The best performing concentration-based index is $A O T_{60}\left(\mathrm{R}^{2}=0.91\right.$, Fig. $\left.4 \mathrm{~B}\right)$. The regression relationships of $R B$ for $P O D_{1}$ and $P O D_{7}$ are illustrated in Fig. $4 C$ and D, with determination coefficients of 0.85 and 0.91 , respectively. Based on the relationships illustrated in Fig. 4, the critical levels of $A O T_{40}, A O T_{60}, P O D_{1}$, and $P O D_{7}$ for a $5 \%$ reduction of total biomass for poplar were $12.0 \mu \mathrm{mol} \mathrm{mol}^{-1} \mathrm{~h}, 9.4 \mu \mathrm{mol} \mathrm{mol}^{-1} \mathrm{~h}$, $6.1 \mathrm{mmol} \mathrm{m}^{-2}$, and $3.8 \mathrm{mmol} \mathrm{m}^{-2}$, respectively.

Fig. 5 illustrates the relationships between the estimated $\mathrm{O}_{3}$ flux above the threshold $7 \mathrm{nmol} \mathrm{O}_{3} \mathrm{~m}^{-2}$ PLA s${ }^{-1}$ and the $\mathrm{O}_{3}$ concentration. The minimum $\mathrm{O}_{3}$ concentration, above which there could be a theoretical contribution to $\mathrm{POD}_{7}$ varies between 28 and $36 \mathrm{nmol} \mathrm{mol}^{-1}$ for five poplar clones according to their respective value for $g_{\text {sto. }}$. It is clear that the ambient 8-h (09:00-17:00) average $\mathrm{O}_{3}$ concentration $\left(68.3 \pm 2.3 \mathrm{nmol} \mathrm{mol}{ }^{-1}\right.$, mean $\left.\pm \mathrm{SE}\right)$ during the experiment period was already affecting poplar growth. As shown in Fig. 5, poplar ' 546 ' had the lowest intercept on the $x$-axis and the highest slope among all five clones and the opposite was true for poplar ' 90 '. The smaller the $x$-axis intercept and the higher the slope are, the greater is the potential for $\mathrm{O}_{3}$ damage.

Table 2

Parameterization for the stomatal conductance model for five poplar clones.

\begin{tabular}{|c|c|c|c|c|c|c|}
\hline Parameter & Units & $84 \mathrm{~K}$ & 107 & 90 & 546 & 156 \\
\hline$g_{\max }$ & $\mathrm{mmol} \mathrm{O}_{3} \mathrm{~m}^{-2} \mathrm{PLA} \mathrm{s}^{-1}$ & 299.8 & 275.2 & 240.3 & 343.9 & 322.4 \\
\hline$f_{\min }$ & Fraction & 0.01 & 0.01 & 0.01 & 0.01 & 0.01 \\
\hline$f_{\text {phen_a }}$ & Fraction & - & -0.09 & - & - & - \\
\hline$f_{\text {phen_b }}$ & Fraction & 0.006 & 0.798 & 0.512 & 0.665 & 0.327 \\
\hline$f_{\text {phen_c }}$ & day & - & 80 & - & - & - \\
\hline$f_{\text {phen_d }}$ & day & 83 & 15 & 32 & 16 & 22 \\
\hline$T_{\min }$ & ${ }^{\circ} \mathrm{C}$ & 23.2 & 13.7 & 17.0 & 16.5 & 23.2 \\
\hline$T_{\mathrm{opt}}$ & ${ }^{\circ} \mathrm{C}$ & 33.5 & 30.7 & 30.8 & 29.7 & 32.5 \\
\hline$T_{\max }$ & ${ }^{\circ} \mathrm{C}$ & 46.9 & 44.2 & 43.7 & 39.1 & 38.6 \\
\hline light $_{\mathrm{a}}$ & Constant & $3.3 \times 10^{-3}$ & $4.6 \times 10^{-3}$ & $5.9 \times 10^{-3}$ & $3.8 \times 10^{-3}$ & $4.0 \times 10^{-3}$ \\
\hline$V P D_{\min }$ & $\mathrm{kPa}$ & 8.4 & 8.2 & 7.2 & 5.2 & 6.4 \\
\hline$V P D_{\max }$ & $\mathrm{kPa}$ & 2.5 & 2.5 & 3.0 & 2.2 & 1.8 \\
\hline
\end{tabular}




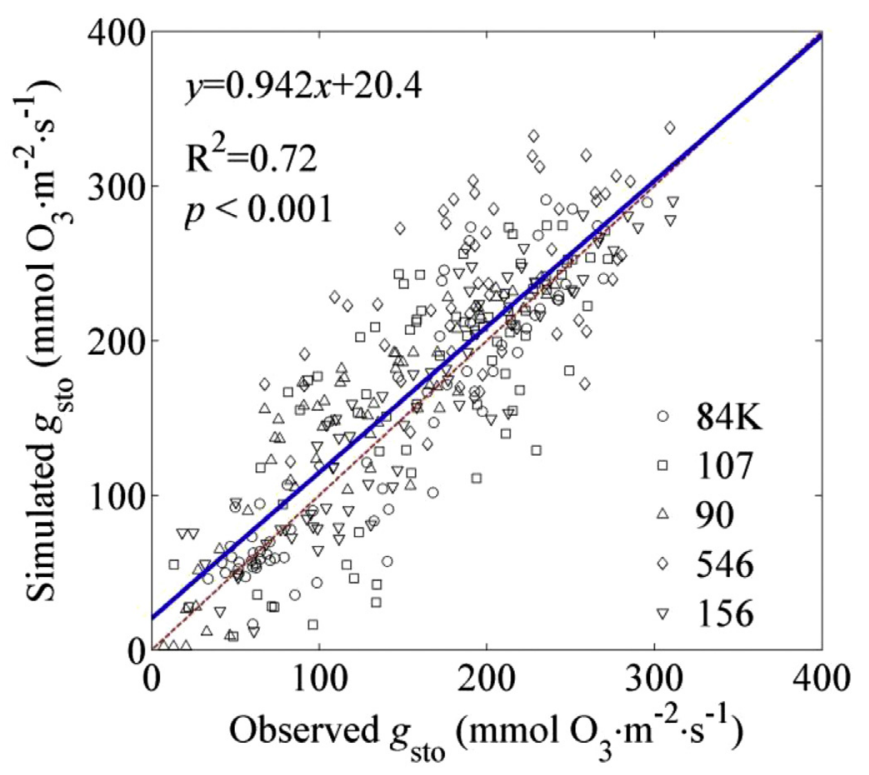

Fig. 2. Simulated versus observed stomatal conductance $\left(g_{\text {sto }}\right)$ of five poplar clones from NF and NF+40 treatments. Blue solid line represents regression, and red dashed line denotes theoretical 1:1 relationship. (For interpretation of the references to color in this figure legend, the reader is referred to the web version of this article.)

\section{Discussion}

To develop the flux-based $\mathrm{O}_{3}$ dose-response relationship for poplar in China, a factorial Jarvis-type stomatal conductance model was parameterized using the measurements of $g_{\text {sto }}$ and corresponding meteorological and phenological data. In previous studies, the maximum stomatal conductance $\left(g_{\max }\right)$ was measured under optimal conditions where there is no limiting effect of VPD, $P P F D$, and $\mathrm{O}_{3}$. However, such optimal conditions are hardly achieved during measurements. On the contrary, fitting the observed $g_{\text {sto }}$ into a bell-shaped equation (Eq. (10)) using a boundary analysis technique can extrapolate the $g_{\max }$ from the optimum of the curve. The maximum $g_{\text {sto }}$ measured in this experiment was 295.7, 272.5, 240.7, 309.3 and $311.2 \mathrm{mmol} \mathrm{O}_{3} \mathrm{~m}^{-2}$ PLA s$^{-1}$ for ' $84 \mathrm{~K}$ ', '107', '90', '546' and '156', respectively. The estimated $g_{\max }$ from the bellshaped curve by an improved temperature-effect method in this study were slightly higher than the maximum measurements except for the clone ' 90 ', suggesting that using the maximum of random measurements may underestimate stomatal $\mathrm{O}_{3}$ flux. The averaged $g_{\max }\left(296.3 \mathrm{mmol} \mathrm{O}_{3} \mathrm{~m}^{-2}\right.$ PLA s$\left.{ }^{-1}\right)$ for poplar is higher than for beech (205 $\mathrm{mmol} \mathrm{O}_{3} \mathrm{~m}^{-2}$ PLA s$^{-1}$, Azuchi et al. (2014)) and oak (255-285 $\mathrm{mmol} \mathrm{O}_{3} \mathrm{~m}^{-2}$ PLA s$^{-1}$, Hoshika et al. (2011)) in East Asia, as well as birch in Continental Central Europe $\left(150 \mathrm{mmol} \mathrm{O}_{3}\right.$ $\mathrm{m}^{-2}$ PLA s${ }^{-1}$, LRTAP Convention (2010)) and in North America (230 $\mathrm{mmol} \mathrm{O}_{3} \mathrm{~m}^{-2}$ PLA s $^{-1}$, Uddling et al. (2010)). Even though VPD was estimated using air temperature and relative humility in the present study, the correlation coefficient between $f_{\mathrm{VPD}}$ and $f_{\text {temp }}$ was very small (0.094), which is in agreement with the results reported by Pleijel et al. (2002). The Jarvis-type Eq. (2) is a mathematical model multiplying $g_{\max }$ by the limiting functions of phenology and environmental factors. The ability of this model to predict $g_{\text {sto }}$ needs to be validated by comparing the observations and simulations, even though each limiting function was calibrated based on the experimental data using a boundary line technique (Azuchi et al., 2014). The determination coefficient of the regression between calculated and observed $g_{\text {sto }}$ across all five poplar clones in the present study was 0.72 .
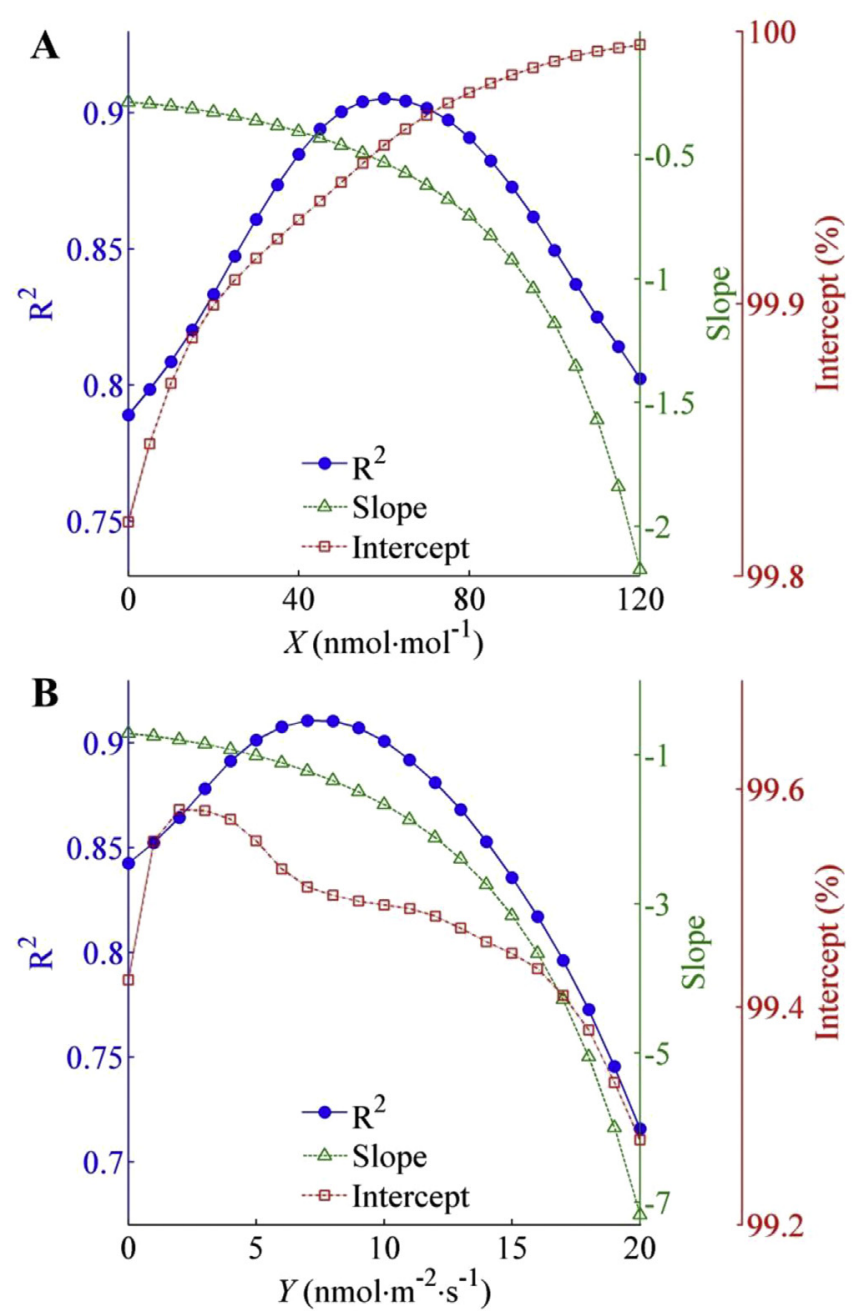

Fig. 3. Coefficient of determination $\left(R^{2}\right)$, slope and intercept (\%) of regressions between relative biomass $\left(R B, \%, y\right.$-axis) and accumulated $\mathrm{O}_{3}$ exposure over an hourly cut-off threshold concentration of $X \mathrm{nmol} \mathrm{mol}^{-1}$ during daylight hours (AOT,$X$-axis) (A) or between relative biomass $\left(R B, \%, y\right.$-axis) and estimated accumulated stomatal $\mathrm{O}_{3}$ flux over a threshold of $Y$ nmol $O_{3} \mathrm{~m}^{-2}$ PLA s $^{-1}\left(P O D_{\mathrm{Y}}, x\right.$-axis) (B).

The dose-response relationships between $\mathrm{O}_{3}$ metrics and relative biomass for poplar were developed. The regressions based on both concentration-based $A O T$ indices and flux-based $P O D$ indices are all highly significant $(p<0.001)$. Among all AOT indices for the same accumulation period, the determination coefficient of the regression between $R B$ and $A O T_{60}$ is the highest (0.91). For $A O T_{40}$, the regression resulted in a slightly lower, but still acceptable $\mathrm{R}^{2}$ value of 0.88 . The AOT indices are based only on the concentration of $\mathrm{O}_{3}$ during daylight hours and have no sensitivity at all to the factors which influence $\mathrm{O}_{3}$ uptake by plants. The stomatal flux-response index $P O D_{7}$ led to the highest $\mathrm{R}^{2}$ value $(0.91)$ in the regression between $R B$ and $P O D$. The intercepts did not statistically differ from $100 \%$ for any of the $\mathrm{O}_{3}$ indices presented in Fig. 4. However, the intercepts on $y$-axis for the regression between $R B$ and $P O D$ indices were slightly lower than that for the regression between $R B$ and $A O T$ indices.

Both $A O T$-based and $P O D$-based dose-response relationships performed similar with respect to biomass reduction for poplars in China, as indicated by similar $\mathrm{R}^{2}$ value. Similar results were also found for winter wheat (Triticum aestivum L.) grown in subtropical China (Feng et al., 2012) and UK (Gonzalez-Fernandez et al., 2010). Nevertheless, most European studies found that flux-based 

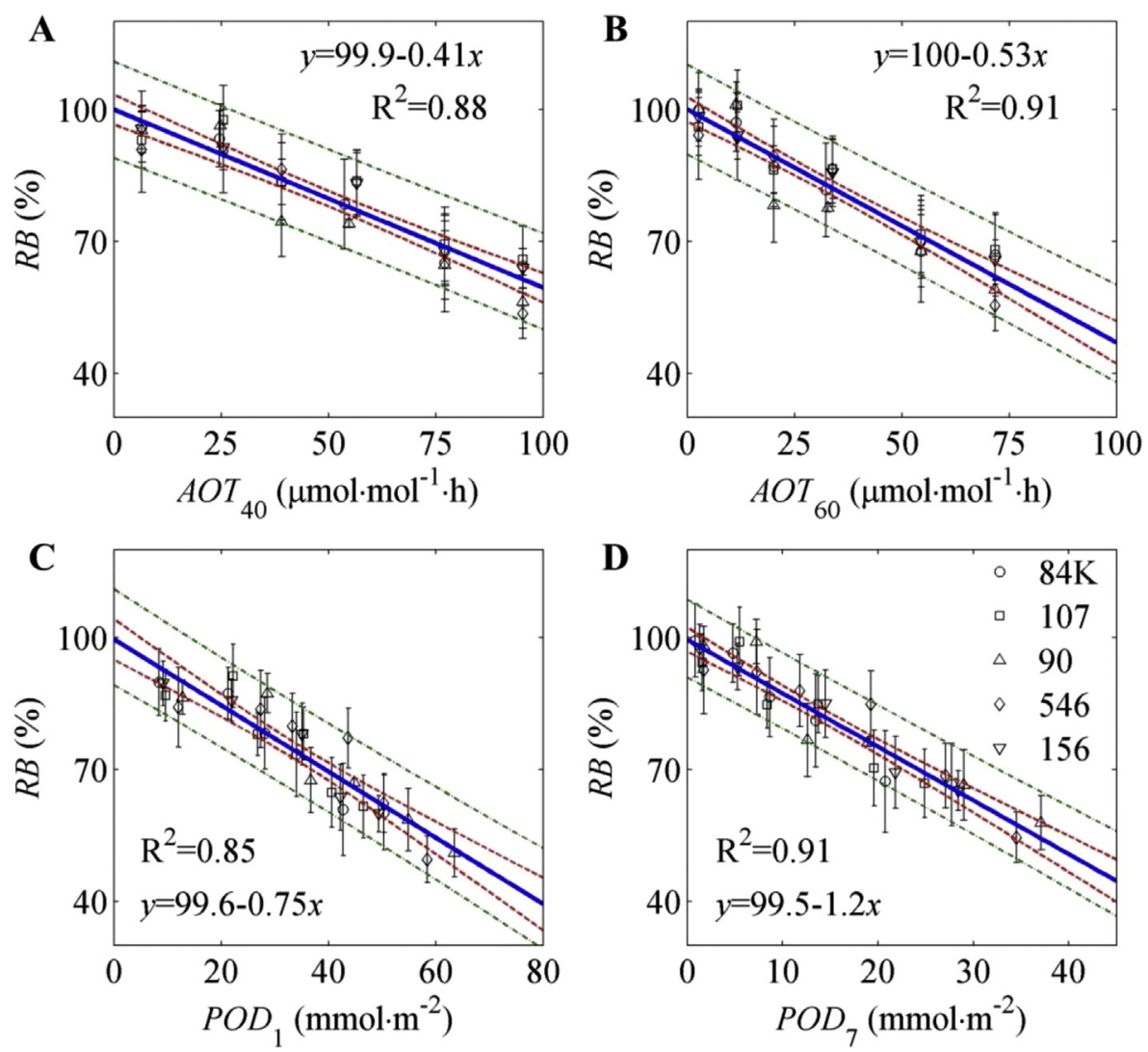

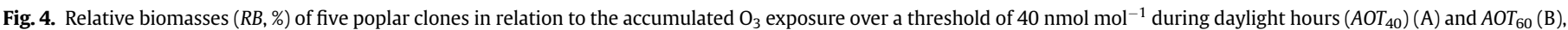

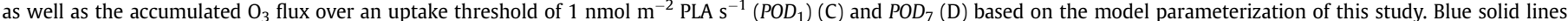

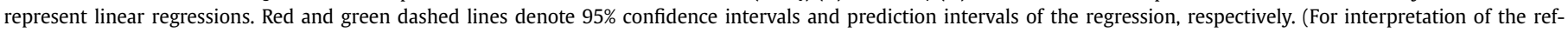
erences to color in this figure legend, the reader is referred to the web version of this article.)

dose-response relationship provided a higher $\mathrm{R}^{2}$ value than concentration-based exposure indices in assessing $\mathrm{O}_{3}$-induced biomass loss of wheat (T. aestivum L., Danielsson et al., 2003; Pleijel et al., 2004), potato (Solanum tuberosum L., Pleijel et al., 2002, 2004), timothy (Phleum pretense, Danielsson et al., 2013), juvenile silver birch (Betula pendula Roth, Uddling et al., 2004), and subterranean clover (Trifolium subterraneum L., cv. Geraldton, Karlsson et al., 2004). The $P O D$-based approach is more analytic to explain the stomatal limitation on $\mathrm{O}_{3}$ uptake by plants. Its performance may highly depend on the experimental conditions, such as temperature and soil water content.

$A O T_{40}$ has been regarded and retained as the basis for the $\mathrm{O}_{3}$ critical levels for trees because it has a relatively simple definition to make calculations easy (LRTAP Convention, 2010). However, it is not sufficiently robust to apply to sensitive plants growing under a diverse range of climates (Karlsson et al., 2004). The POD approach is more complicated and requires more data. But it could take into account the stomatal limitation on $\mathrm{O}_{3}$ uptake. $P O D_{\mathrm{Y}}$ is more biologically realistic than $A T_{40}$, since the impact of $\mathrm{O}_{3}$ on plants depends on the amount of $\mathrm{O}_{3}$ entering the stomata and its detoxification by antioxidants (Emberson et al., 2000a; Matyssek et al., 2007; Zona et al., 2014). Thus, from a mechanistic point of view it seems to be a step forward to promote this flux-based approach (Danielsson et al., 2003; Mills et al., 2011; Paoletti and Manning, 2007; Pleijel et al., 2004; Uddling et al., 2004).

The critical level based on the $A O T_{40}$-response relationship with regard to $5 \%$ reduction in total biomass for poplar was $12 \mu \mathrm{mol} \mathrm{mol}{ }^{-1} \mathrm{~h}$, which is 2.4 times the critical value $\left(5 \mu \mathrm{mol} \mathrm{mol}{ }^{-1} \mathrm{~h}\right)$ reported for birch and beech species in Europe
(LRTAP Convention, 2010). The $A O T_{40}$ value accumulated using ambient $\mathrm{O}_{3}$ concentration over the same duration in the experimental site was $40.5 \mu \mathrm{mol} \mathrm{mol}^{-1} \mathrm{~h}$, which corresponded to $16.7 \%$ loss of total poplar biomass. Expert judgment was used to set the flux-based threshold $Y$ to $1 \mathrm{nmol} \mathrm{O}_{3} \mathrm{~m}^{-2} \mathrm{PLA} \mathrm{s}^{-1}$ to represent the detoxification capacity for forest trees (LRTAP Convention, 2010; Pleijel et al., 2004). The critical levels of $P O D_{1}$ for $4 \%$ biomass loss of beech/birth and $2 \%$ biomass loss of Norway spruce were defined as $4 \mathrm{mmol} \mathrm{m}^{-2}$ and $8 \mathrm{mmol} \mathrm{m}^{-2}$, respectively (LRTAP Convention, 2010). Using the $P O D_{1}$ dose-response relationship for poplar resulted in a $2 \%$ biomass loss at $2.1 \mathrm{mmol} \mathrm{m}^{-2}$ and a $4 \%$ loss at $4.8 \mathrm{mmol} \mathrm{m}^{-2}$. The slope of the $P O D_{1}$-response relationship in the poplars suggests that ozone effects per unit ozone uptake of poplar was similar to that of European beech/birch, and was steeper than that of spruce. This means the capacity of tolerance such as biochemical detoxification or repair may be similar between poplar and European beech/birch. It is somewhat inconsistent with the previous observations reported that fast-growing tree species, such as most poplar clones and hybrids, are more sensitive and responsive to tropospheric $\mathrm{O}_{3}$ than slower-growing species, such as beech (Bortier et al., 2000; Novak et al., 2003, 2005), because poplar has a relatively high stomatal conductance and thus high $\mathrm{O}_{3}$ uptake (Pye, 1988; Zona et al., 2014). The comparisons of flux- and concentration-based critical levels between poplar examined in the present study and beech/birch in Europe may also suggest that the same $A O T_{40}$-based critical level cannot be applied for the tree species even with the similar sensitivity to $\mathrm{O}_{3}$.

$\mathrm{POD}_{7}$ will start to accumulate at a threshold $\mathrm{O}_{3}$ concentration of approximately $28-36 \mathrm{nmol} \mathrm{mol}^{-1}$ due to high $g_{\text {sto }}$ in poplar clones. 

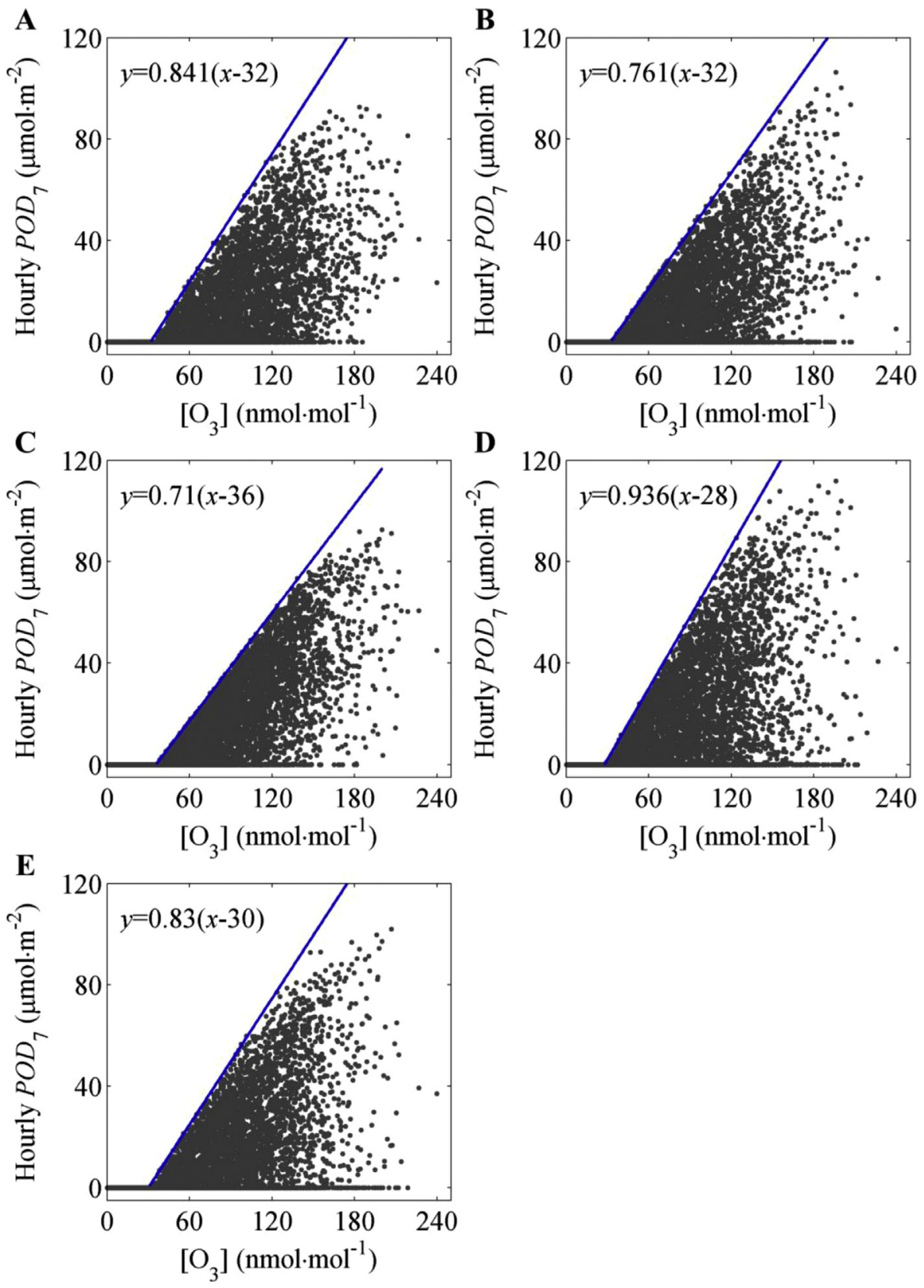

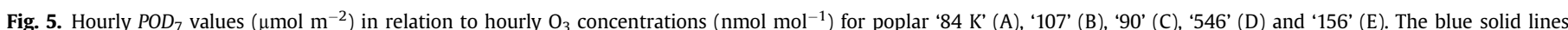

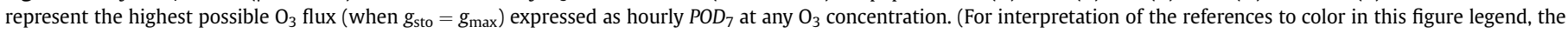
reader is referred to the web version of this article.)

Ozone uptake at concentrations above this threshold value has the potential to cause biomass loss in poplar. Unlike AOT indices, such concentration threshold and the size of the contribution to $\mathrm{POD}_{7}$ depend strongly on $g_{\text {sto }}$ of different poplar clones. For ' 546 ' with the maximum $g_{\text {max }}$, the threshold is the smallest $\left(28 \mathrm{nmol} \mathrm{mol}^{-1}\right)$ and the slope is the highest (0.94). In contrast, for ' 90 ' with the minimum $g_{\max }$, the threshold is greatest $\left(36 \mathrm{nmol} \mathrm{mol}^{-1}\right.$ ) and the slope is lowest (0.71). Moreover, at concentrations slightly above this threshold value, the contribution to $\mathrm{POD}_{7}$ is small even if $g_{\text {sto }}$ is close to $g_{\max }$. At higher $\mathrm{O}_{3}$ concentrations, the contribution to $\mathrm{POD}_{7}$ would be much greater, whereas was limited by $g_{\text {sto }}$ to the extent of $g_{\text {max. }}$

There are over 7 million ha of poplar plantation in China, constituting $19 \%$ of the total forest plantation area (Xu et al., 2009).
As one of the representative deciduous broadleaved tree species of plantations, poplar is under the risk of $\mathrm{O}_{3}$ damage due to current ground-level $\mathrm{O}_{3}$ pollution in China (Feng et al., 2015; Zhang et al., 2012). The five poplar clones used in the present study are widely planted in China as plantations, urban landscaping, farmland shelterbelts, as well as industrial timber (Jia et al., 2013). The $\mathrm{O}_{3}$ dose-response relationships based on these five poplar clones could be used to evaluate the worst-case ozone risk on poplars in China (i.e. without water supply limiting stomatal conductance). Admittedly, a more comprehensive experiment with more poplar clones at different climate conditions, and with the observation of soil water potential could improve the stomatal conductance model and thus $\mathrm{O}_{3}$ dose-response relationship for poplar risk assessment. 


\section{Acknowledgements}

This study has been funded by the Hundred Talents Program, Chinese Academy of Sciences, State Key Laboratory of Desert and Oasis Ecology, Xinjiang Institute of Ecology and Geography, Chinese Academy of Sciences, and the National Natural Science Foundation of China (No. 41401225). We thank Dr. Harry Harmens for English improvement throughout the manuscript.

\section{Appendix A. Supplementary data}

Supplementary data related to this article can be found at http:// dx.doi.org/10.1016/j.envpol.2015.08.034.

\section{References}

Azuchi, F., Kinose, Y., Matsumura, T., Kanomata, T., Uehara, Y., Kobayashi, A Yamaguchi, M., Izuta, T., 2014. Modeling stomatal conductance and ozone uptake of Fagus crenata grown under different nitrogen loads. Environ. Pollut. 184, $481-487$.

Bernacchi, C.J. Calfapietra, C., Davey, P.A., Wittig, V.E, Scarascia-Mugnozza, G.E Raines, C.A., Long, S.P., 2003. Photosynthesis and stomatal conductance responses of poplars to free-air $\mathrm{CO}_{2}$ enrichment (PopFACE) during the firs growth cycle and immediately following coppice. New Phytol. 159, 609-621.

Bhat, R., Sujatha, S., 2013. Establishing leaf nutrient norms for arecanut by boundary line approach. J. Plant Nutr. 36, 849-862.

Blanco-Macías, F., Magallanes-Quintanar, R., Valdez-Cepeda, R.D., VázquezAlvarado, R., Olivares-Sáenz, E., Gutiérrez-Ornelas, E., Vidales-Contreras, J.A., Murillo-Amador, B., 2010. Nutritional reference values for Opuntia ficus-indica determined by means of the boundary-line approach. J. Plant Nutr. Soil Sci. 173, 927-934.

Bortier, K., Temmerman, L.D., Ceulemans, R., 2000. Effects of ozone exposure in open-top chambers on poplar (Populus nigra) and beech (Fagus sylvatica): a comparison. Environ. Pollut. 109, 509-516.

Calatayud, V., Cervero, J., Calvo, E., Garcia-Breijo, F.J., Reig-Arminana, J., Sanz, M.J. 2011. Responses of evergreen and deciduous Quercus species to enhanced ozone levels. Environ. Pollut. 159, 55-63.

Campbell, G.S., Norman, J.M., 1998. An Introduction to Environmental Biophysics Second Edition. Springer, Verlag, New York, Berlin, Heidelberg.

Castagna, A., Di Baccio, D., Ranieri, A.M., Sebastiani, L., Tognetti, R., 2015. Effects of combined ozone and cadmium stresses on leaf traits in two poplar clones. Environ. Sci. Pollut. Res. 22, 2064-2075.

LRTAP Convention, 2010. Chapter 3. Mapping Critical Levels for Vegetation, Manual on Methodologies and Criteria for Modeling and Mapping Critical Loads \& Levels and Air Pollution Effects, Risk and Trends. Available from: icpvegetation. ceh.ac.uk.

Danielsson, H., Karlsson, G.P., Karlsson, P.E., Pleijel, H.H., 2003. Ozone uptake modelling and flux-response relationships-an assessment of ozone-induced yield loss in spring wheat. Atmos. Environ. 37, 475-485.

Danielsson, H., Karlsson, P.E., Pleijel, H., 2013. An ozone response relationship for four Phleum pratense genotypes based on modelling of the phytotoxic ozone dose (POD). Environ. Exp. Bot. 90, 70-77.

Dumont, J., Spicher, F., Montpied, P., Dizengremel, P., Jolivet, Y. Le Thiec, D., 2013. Effects of ozone on stomatal responses to environmental parameters (blue light, red light, $\mathrm{CO}_{2}$ and vapour pressure deficit) in three Populus deltoides $\times$ Populus nigra genotypes. Environ. Pollut. 173, 85-96.

Dumont, J., Cohen, D., Gérard, J., Jolivet, Y., Dizengremel, P., Le Theic, D., 2014. Distinct responses to ozone of abaxial and adaxial stomata in three Euramerican poplar genotypes. Plant Cell Environ. 37, 2064-2076.

Emberson, L.D., Ashmore, M.R., Cambridge, H.M., Simpson, D., Tuovinen, J.-P., 2000 Modelling stomatal ozone flux across Europe. Environ. Pollut. 109, 403-413.

Emberson, L.D., Wieser, G., Ashmore, M.R., 2000b. Modelling of stomatal conductance and ozone flux of Norway spruce: comparison with field data. Environ. Pollut. 109, 393-402.

FAO, 2010. Global Forest Resources Assessment 2010: Main Report, FAO Foresty Paper 163. Food and Agriculture Organization of the United Nations, Rome.

Felzer, B.S., Cronin, T., Reilly, J.M., Melillo, J.M., Wang, X., 2007. Impacts of ozone on trees and crops. Comptes Rendus Geosci. 339, 784-798.

Feng, Z., Pang, J., Nouchi, I., Kobayashi, K., Yamakawa, T., 2010. Apoplastic ascorbate contributes to the differential ozone sensitivity in two varieties of winter wheat under fully open-air field conditions. Environ. Pollut. 158, 3539-3545.

Feng, Z., Niu, J., Zhang, W., Wang, X., Yao, F., Tian, Y., 2011. Effects of ozone exposure on sub-tropical evergreen Cinnamomum camphora seedlings grown in different nitrogen loads. Trees 25, 617-625.

Feng, Z., Tang, H., Uddling, J., Pleijel, H., Kobayashi, K., Zhu, J., Oue, H., Guo, W., 2012. A stomatal ozone flux-response relationship to assess ozone-induced yield loss of winter wheat in subtropical China. Environ. Pollut. 164, 16-23.

Feng, Z., Sun, J., Wan, W., Hu, E., Calatayud, V., 2014. Evidence of widespread ozoneinduced visible injury on plants in Beijing, China. Environ. Pollut. 193, 296-301.

Feng, Z., Hu, E., Wang, X., Jiang, L., Liu, X., 2015. Ground-level $\mathrm{O}_{3}$ pollution and it impacts on food crops in China: a review. Environ. Pollut. 199, 42-48.

Fowler, D., Pilegaard, K., Sutton, M.A., Ambus, P., Raivonen, M., Duyzer, J., Simpson, D., Fagerli, H., Fuzzi, S., Schjoerring, J.K., Granier, C., Neftel, A. Isaksen, I.S.A., Laj, P., Maione, M., Monks, P.S., Burkhardt, J., Daemmgen, U., Neirynck, J., Personne, E., Wichink-Kruit, R., Butterbach-Bahl, K., Flechard, C., Tuovinen, J.P. Coyle, M. Gerosa, G, Loubet, B. Altimir, N. Gruenhage, L, Ammann, C., Cieslik, S., Paoletti, E., Mikkelsen, T.N., Ro-Poulsen, H., Cellier, P., Cape, J.N., Horváth, L., Loreto, F., Niinemets, Ü., Palmer, P.I., Rinne, J., Misztal, P., Nemitz, E., Nilsson, D., Pryor, S., Gallagher, M.W., Vesala, T., Skiba, U., Brüggemann, N., Zechmeister-Boltenstern, S., Williams, J., O'Dowd, C., Facchini, M.C., de Leeuw, G., Flossman, A., Chaumerliac, N., Erisman, J.W., 2009. Atmospheric composition change: ecosystems-atmosphere interactions. Atmos. Environ, 43, 5193-5267.

Fuhrer, J., 1994. The critical level for ozone to protect agricultural crops - an assessment of data from European open-top chamber experiments. In: Fuhrer, J., Achermann, B. (Eds.), Critical levels for ozone. A UN-ECE workshop report. Schriftenreihe der FAC Liebefeld, p. 16, 42-57.

Fuhrer, J., Skärby, L., Ashmore, M.R., 1997. Critical levels for ozone effects on vegetation in Europe. Environ. Pollut. 97, 91-106.

Gerosa, G. Fusaro, L., Monga, R., Finco, A., Fares, S., Manes, F., Marzuoli, R. 2015. A flux-based assessment of above and below ground biomass of Holm oak (Quercus ilex L.) seedlings after one season of exposure to high ozone concentrations. Atmos. Environ. 113, 41-49.

Gonzalez-Fernandez, I., Kaminska, A., Dodmani, M., Goumenaki, E., Quarrie, S., Barnes, J.D., 2010. Establishing ozone flux-response relationships for winter wheat: analysis of uncertainties based on data for UK and polish genotypes. Atmos. Environ. 44, 621-630.

Guidi, L., Nali, C., Lorenzini, G., Filippi, F., Soldatini, G.F., 2001. Effect of chronic ozone fumigation on the photosynthetic process of poplar clones showing different sensitivity. Environ. Pollut. 113, 245-254.

Häikiö, E., 2009. Clonal Differences of Aspen (Populus spp.) in Responses to Elevated Ozone and Soil Nitrogen, Department of Environmental Science. University of Kuopio, Kuopio, p. 49

Hoshika, Y. Hajima, T, Shimizu, Y, Takigawa, M. Omasa, K, 2011. Estimation of stomatal ozone uptake of deciduous trees in East Asia. Ann. For. Sci. 68, $607-616$.

Hoshika, Y, Omasa, K. Paoletti, E., 2012. Whole-tree water use efficiency is decreased by ambient ozone and not affected by $\mathrm{O}_{3}$-induced stomatal sluggishness. PLoS One 7, e39270.

Imhoff, S., Kay, B.D., da Silva, A.P., Hajabbasi, M.A., 2010. Evaluating responses of maize (Zea mays L.) to soil physical conditions using a boundary line approach. Soil Tillage Res. 106, 303-310.

IPCC, 2013. In: Stocker, T.F., Qin, D., Plattner, G.-K., Tignor, M.M.B., Allen, S.K., Boschung, J., Nauels, A., Xia, Y., Bex, V., Midgley, P.M. (Eds.), Climate Change 2007: The Physical Science Basis. Contribution of Working Group I to the Fifth Assessment Report of the Intergovernmental Panel on Climate Change. Intergovernmental Panel on Climate Change, p. 1552. New York, USA

Isebrands, J.G. McDonald, E.P., Kruger, E., Hendrey, G., Percy, K., Pregitzer, K., Sober, J., Karnosky, D.F., 2001. Growth responses of Populus tremuloides clones to interacting elevated carbon dioxide and tropospheric ozone. Environ. Pollut. $115,359-371$

Jarvis, P.G., 1976. The interpretation of the variations in leaf water potential and stomatal conductance found in canopies in the field. Philosophical Trans. R. Soc. B Biol. Sci. 273, 593-610.

Jia, L., Liu, S., Zhu, L., Hu, J., Wang, X., 2013. Carbon storage and density of poplars in China. J. Nanjing For. Univ. Nat. Sci. Ed. 37, 1-7 (in Chinese).

Jones, H., 1983. Plants and Microclimate. A Quantitative Approach to Environmental Plant Physiology. Cambridge University Press, Cambridge, UK, p. 323.

Karlsson, G.P., Karlsson, PE., Soja, G., Vandermeiren, K., Pleijel, H., 2004 Test of the short-term critical levels for acute ozone injury on plants-improvements by ozone uptake modelling and the use of an effect threshold. Atmos. Environ. 38, 2237-2245.

Kerstiens, G., Lendzian, K.J., 1989. Interactions between ozone and plant cuticles I. Ozone deposition and permeability. New Phytol. 112, 13-19.

Koch, J.R., Scherzer, A.J., Eshita, S.M., Davis, K.R., 1998. Ozone sensitivity in hybrid poplar is correlated with a lack of defense-gene activation. Plant Physiol. 118, 1243-1252.

Kopper, B.J., Lindroth, R.L., 2003. Effects of elevated carbon dioxide and ozone on the phytochemistry of aspen and performance of an herbivore. Oecologia 134, 95-103.

Laisk, A., Kull, O., Moldau, H., 1989. Ozone concentration in leaf intercellular air spaces is close to zero. Plant Physiol. 90, 1163-1167.

Lewandowski, I., Schmidt, U., 2006. Nitrogen, energy and land use efficiencies of miscanthus, reed canary grass and triticale as determined by the boundary line approach. Agriculture. Ecosyst. Environ. 112, 335-346.

Liang, W., Hu, H., Liu, F., Zhang, D., 2006. Research advance of biomass and carbon storage of poplar in China. J. For. Res. 17, 75-79.

Matyssek, R., Günthardt-Goerg, M.S., Landolt, W., Keller, T., 1993. Whole-plant growth and leaf formation in ozonated hybrid poplar (Populus $\times$ euramericana). Environ. Pollut. 81, 207-212.

Matyssek, R., Bytnerowicz, A., Karlsson, P.E., Paoletti, E., Sanz, M., Schaub, M., Wieser, G., 2007. Promoting the $\mathrm{O}_{3}$ flux concept for European forest trees. Environ. Pollut. 146, 587-607.

Mills, G., Pleijel, H., Braun, S., Büker, P., Bermejo, V., Calvo, E., Danielsson, H., Emberson, L., Fernández, I.G., Grünhage, L., Harmens, H., Hayes, F., Karlsson, P.- 
E., Simpson, D., 2011. New stomatal flux-based critical levels for ozone effects on vegetation. Atmos. Environ. 45, 5064-5068.

Mooi, J., 1980. Influence of ozone on growth of two poplar cultivars. Plant Dis. 64, $772-773$.

Morgan, P.B., Mies, T.A., Bollero, G.A., Nelson, R.L., Long, S.P., 2006. Season-long elevation of ozone concentration to projected 2050 levels under fully open-air conditions substantially decreases the growth and production of soybean. New Phytol. 170, 333-343.

Novak, K., Skelly, J.M., Schaub, M., Kräuchi, N., Hug, C., Landolt, W., Bleuler, P., 2003. Ozone air pollution and foliar injury development on native plants of Switzerland. Environ. Pollut. 125, 41-52.

Novak, K., Schaub, M., Fuhrer, J., Skelly, J.M., Hug, C., Landolt, W., Bleuler, P., Krauchi, N., 2005. Seasonal trends in reduced leaf gas exchange and ozoneinduced foliar injury in three ozone sensitive woody plant species. Environ. Pollut. 136, 33-45.

Paoletti, E., Grulke, N.E., 2010. Ozone exposure and stomatal sluggishness in different plant physiognomic classes. Environ. Pollut. 158, 2664-2671.

Paoletti, E., Manning, W.J., 2007. Toward a biologically significant and usable standard for ozone that will also protect plants. Environ. Pollut. 150, 85-95.

Percy, K.E., Karnosky, D.F., 2007. Air quality in natural areas: interface between the public, science and regulation. Environ. Pollut. 149, 256-267.

Pleijel, H., Danielsson, H., Vandermeiren, K., Blum, C., Colls, J., Ojanperä, K., 2002. Stomatal conductance and ozone exposure in relation to potato tuber yield - results from the European CHIP programme. Eur. J. Agron. 17, 303-317.

Pleijel, H., Danielsson, H., Ojanperä, K., Temmerman, L.D., Högy, P., Badiani, M., Karlsson, P.E., 2004. Relationships between ozone exposure and yield loss in European wheat and potato-a comparison of concentration- and flux-based exposure indices. Atmos. Environ. 38, 2259-2269.

Potvin, C., Tardif, S., 1988. Sources of variability and experimental designs in growth chambers. Funct. Ecol. 2, 123-130.

Pye, J.M., 1988. Impact of ozone on the growth and yield of trees: a review. J. Environ. Qual. 17, 347-360.

Ranieri, A., Giuntini, D., Ferraro, F., Nali, C., Baldan, B., Lorenzini, G., Soldatini, G.F., 2001. Chronic ozone fumigation induces alterations in thylakoid functionality and composition in two poplar clones. Plant Physiology Biochem. 39, 999-1008.

Richet, N., Afif, D., Huber, F., Pollet, B., Banvoy, J., El Zein, R., Lapierre, C., Dizengremel, P., Perré, P., Cabané, M., 2011. Cellulose and lignin biosynthesis is altered by ozone in wood of hybrid poplar (Populus tremula $\times$ alba). J. Exp. Bot. $62,3575-3586$.

Richet, N., Afif, D., Tozo, K., Pollet, B., Maillard, P., Huber, F., Priault, P., Banvoy, J., Gross, P., Dizengremel, P., Lapierre, C., Perré, P., Cabané, M., 2012. Elevated $\mathrm{CO}_{2}$ and/or ozone modify lignification in the wood of poplars (Populus tremula $\times$ alba). J. Exp. Bot. 63, 4291-4301.

Ryan, A., Cojocariu, C., Possell, M., Davies, W.J., Hewitt, C.N., 2009. Defining hybrid poplar (Populus deltoides $\times$ Populus trichocarpa) tolerance to ozone: identifying key parameters. Plant Cell Environ. 32, 31-45.

Schmidt, U., Thöni, H., Kaupenjohann, M., 2000. Using a boundary line approach to analyze $\mathrm{N}_{2} \mathrm{O}$ flux data from agricultural soils. Nutrient Cycl. Agroecosyst. 57, 119-129.

Sitch, S., Cox, P.M., Collins, W.J., Huntingford, C., 2007. Indirect radiative forcing of climate change through ozone effects on the land-carbon sink. Nature 448 $791-794$.

Strohm, M., Eiblmeier, M., Langebartels, C., Jouanin, L., Polle, A., Sandermann, H., Rennenberg, H., 1998. Responses of transgenic poplar (Populus tremula $\times$ P. alba) overexpressing glutathione synthetase or glutathione reductase to acute ozone stress: visible injury and leaf gas exchange. J. Exp. Bot. 50, 365-374.

Topp, C., Wang, W., Cloy, J., Rees, R., Hughes, G., 2013. Information properties of boundary line models for $\mathrm{N}_{2} \mathrm{O}$ emissions from agricultural soils. Entropy 15 , 972-982.

Uddling, J., Günthardt-Goerg, M.S., Matyssek, R., Oksanen, E., Pleijel, H., Selldén, G., Karlsson, P.E., 2004. Biomass reduction of juvenile birch is more strongly related to stomatal uptake of ozone than to indices based on external exposure. Atmos. Environ. 38, 4709-4719.

Uddling, J., Hogg, A.J., Teclaw, R.M., Carroll, M.A., Ellsworth, D.S., 2010. Stomatal uptake of $\mathrm{O}_{3}$ in aspen and aspen-birch forests under free-air $\mathrm{CO}_{2}$ and $\mathrm{O}_{3}$ enrichment. Environ. Pollut. 158, 2023-2031.

Unsworth, M.H., Heagle, A.S., Heck, W.W., 1984. Gas exchange in open-top field chambers-II. Resistances to ozone uptake by soybeans. Atmos. Environ. 18, $381-385$.

Vingarzan, R., 2004. A review of surface ozone background levels and trends. Atmos. Environ. 38, 3431-3442.

Vizcayno-Soto, G., Côté, B., 2004. Boundary-line approach to determine standards of nutrition for mature trees from spatial variation of growth and foliar nutrient concentrations in natural environments. Commun. Soil Sci. Plant Analysis 35, 2965-2985.

Webb, R.A., 1972. Use of the boundary line in the analysis of biological data. J. HortScience 47, 309-319.

Woo, S.Y., Hinckley, T.M., 2005. The effects of ozone on growth and stomatal response in the F2 generation of hybrid poplar (Populus trichocarpa $\times$ Populus deltoides). Biol. Plant. 49, 395-404.

Xu, M., Zhou, X., Piao, C., 2009. Populus cultivation-clones in different cultivated area and its diseases in China. For. Res. 22, 705-714 (in Chinese).

Zhang, W., Niu, J., Wang, X., Tian, Y., Yao, F., Feng, Z., 2011. Effects of ozone exposure on growth and photosynthesis of the seedlings of Liriodendron chinense (Hemsl.) Sarg, a native tree species of subtropical China. Photosynthetica 49, 29-36.

Zhang, W., Feng, Z., Wang, X., Niu, J., 2012. Responses of native broadleaved woody species to elevated ozone in subtropical China. Environ. Pollut. 163, 149-157.

Zhang, W., Feng, Z., Wang, X., Niu, J., 2014a. Elevated ozone negatively affects photosynthesis of current-year leaves but not previous-year leaves in evergreen Cyclobalanopsis glauca seedlings. Environ. Pollut. 184, 676-681.

Zhang, W., Feng, Z., Wang, X., Niu, J., 2014b. Impacts of elevated ozone on growth and photosynthesis of Metasequoia glyptostroboides Hu et Cheng. Plant Sci. 226, $182-188$.

Zhang, W., Wang, G., Liu, X., Feng, Z., 2014c. Effects of elevated $\mathrm{O}_{3}$ exposure on seed yield, $\mathrm{N}$ concentration and photosynthesis of nine soybean cultivars (Glycine $\max ($ L.) Merr.) in Northeast China. Plant Sci. 226, 172-181.

Zona, D., Gioli, B., Fares, S., De Groote, T., Pilegaard, K., Ibrom, A., Ceulemans, R., 2014. Environmental controls on ozone fluxes in a poplar plantation in Western Europe. Environ. Pollut. 184, 201-210. 